\title{
FAKTOR-FAKTOR YANG MENENTUKAN KEPUTUSAN PEMBELIAN PRODUK VIRTUAL DALAM ONLINE GAMES MOBILE LEGENDS
}

\author{
L.D.Y. Prandini ${ }^{1}$, N.L.W.S. Telagawathi ${ }^{2}$ \\ 1,2 Jurusan Manajemen, Universitas Pendidikan Ganesha, Singaraja \\ e-mail: dithayadnya50@gmail.com, gemilangsuryawan@gmail.com
}

\begin{abstract}
Abstrak
Penelitian ini bertujuan untuk mengetahui (1) faktor-faktor yang menentukan keputusan pembelian produk virtual dalam online games Mobile Legends, dan (2) faktor yang paling dominan menentukan keputusan pembelian produk virtual dalam online games Mobile Legends. Penelitian ini menggunakan jenis penelitian kuantitatif dengan teknik pengumpulan data menggunakan kuesioner dan dianalisis dengan analisis faktor. Sampel dalam penelitian ini adalah mahasiswa Universitas Pendidikan Ganesha dengan teknik purposive sampling. Hasil penelitian ini menunjukkan bahwa (1) faktor-faktor yang menentukan keputusan pembelian produk virtual adalah faktor nilai sosial, faktor nilai fungsional dan faktor nilai emosional, (2) faktor yang dominan menentukan keputusan pembelian produk virtual adalah faktor nilai sosial dengan nilai varimax rotation $31,882 \%$
\end{abstract}

Kata kunci : nilai sosial, nilai fungsional, nilai emosional, online games

\begin{abstract}
This study aims to determine (1) the factors that determine the purchasing decision of virtual products in online games Mobile Legends, and (2) the most dominant factor determining the decision of purchasing virtual products in online games Mobile Legends. This research uses a type of quantitative research with data collection techniques using questionnaires and analyzed with factor analysis. The samples in this study were students of Ganesha University of Education with purposive sampling techniques. The results of this study indicate that (1) the factors that determine the decision to purchase virtual products are social value factors, functional value factors, emotional value factors, and (2) the dominant factor determining virtual product purchasing decisions is the social value factor with varimax rotation value of $31.882 \%$
\end{abstract}

Keywords: emotional value, functional value, online games, social value

\section{Pendahuluan}

Internet merupakan salah satu hal yang umum digunakan oleh masyarakat dunia di jaman modern saat ini. Internet tidak hanya berkembang di negara-negara maju saja, tetapi juga di negara-negara berkembang, salah satunya adalah Indonesia. Menurut Asosiasi Penyelenggara Jasa Internet Indonesia atau (Asosiasi Penyelenggara Jasa Internet Indonesia 2018) salah satu badan survei pengguna internet di Indonesia menyatakan, dari jumlah total penduduk Indonesia yaitu sekitar 264 juta jiwa, ada sebanyak 171,17 juta jiwa atau sekitar 64,8 persen yang sudah menggunakan internet. Perkembangan pengguna internet di Indonesia meningkat setiap tahunnya. Hal ini karena internet miliki kemampuan untuk menghasilkan interaksi tanpa batas ruang dan waktu (Wijaya and Alamanda 2016). Penggunaan internet yang awalnya hanya digunakan sebagai media komunikasi, sekarang dapat digunakan untuk media bisnis, hiburan dan pendidikan. Pemanfaatan internet yang terkenal salah satunya adalah bermain online game (Suryono and Subriadi 2016).

Online game adalah permainan yang dimainkan oleh seorang pemain atau lebih melalui jaringan internet (Yulius 2017). Online game memungkinkan pemain tidak hanya bermain game menggunakan komputer, namun mereka juga dapat terhubung dengan pemain lain melalui internet (Dongseong and Jinwoo 2004). Ketika seorang pemain sering bermain online game, interaksi dengan pemain lainnya akan meningkat, yang kemudian biasanya dapat menyebabkan banyak pemain dapat berperan khusus (berperan sebagai penyedia informasi 
atau sebagai penyedia layanan jasa yang berhubungan dengan game), berinteraksi sosial dengan pemain lain, dan melakukan pertukaran informasi (Suryono and Subriadi 2016).

Kepopuleran online game dan banyaknya jumlah pemain yang semakin meningkat setiap hari menjadikan online game masuk sebagai salah satu cabang olahraga baru dunia yang disebut E-Sport, istilah ini sudah ada sejak tahun 1972 di Stanford University. Perkembangan dunia online game yang signifikan menjadikan industri online game merupakan salah satu bisnis e-commerce yang menjanjikan (Yulius 2017). Pasar game global saat ini menghasilkan pendapatan sebesar $\$ 152,1$ miliar di tahun 2019 dan diperkirakan akan terus meningkat sampai tahun 2022 (Newzoo 2019).

Peningkatan ini didasari oleh semakin banyaknya pemain dan adanya produk virtual di dalam online game yang merupakan barang atau item yang dijual di dalam online game. Produk virtual hanya dijual pada online game berjenis F2P (free to play) Menggunakan kategori bayar per item, game ini gratis. Walaupun merupakan game gratis, pemain juga bisa menggunakan uang sungguhan yang bisa di tukarkan menjadi mata uang digital atau biasa disebut cash untuk jual beli produk virtual, seperti senjata, baju, dan lainnya.

Semenjak diperkenalkan pertama kali di dunia online game, akt ivitas membeli produk virtual dalam online game ini sudah jadi hal yang wajar untuk seorang pemain game (Sari 2018). Penelitian yang dilakukan oleh (Kaburuan, Chen, and Jeng 2009) dari total 111 responden, sebanyak 101 responden pernah melakukan pembelian produk virtual dan 10 responden mengatakan belum pernah melakukan pembeli produk virtual. Hasil dari penelitian mereka juga terdapat $42,86 \%$ yang pernah melakukan pembelian produk virtual adalah mahasiswa. Tingkat antusiasme mahasiswa terbukti cukup tinggi untuk membeli produkproduk virtual yang disediakan oleh para developer. Maka dari itu, peneliti berfokus untuk meneliti pembelian produk virtual yang dilakukan mahasiswa yang ada di Universitas Pendidikan Ganesha.

Online game mobile yang terdapat produk virtual adalah Mobile Legends. Jenis game ini merupakan game MOBA (Multiplayer Online Battle Arena), yaitu Pemain hanya dapat mengontrol satu karakter dan karakter tersebut memiliki atribut dan kemampuan unik yang berbeda dari karakter lain, dan hanya satu tujuan yaitu memenangkan permainan, dengan menghancurkan semua bangunan inti tim lawan (Kevino 2018). Dalam game Mobile Legends, terdapat produk virtual di antaranya: karakter hero, skin karakter, battle emote, emblem, starlight member, twilight pass, dan masih banyak lagi. Untuk dapat membeli produk-produk virtual tersebut, para pemain diharuskan untuk melakukan pembelian diamond terlebih dahulu dengan cara membelinya dengan menggunakan uang riil. Mobile Legends juga aktif mempromosikan produk-produk virtual dan terkadang memberikan beberapa diskon serta hadiah bagi para pemain Mobile Legends. Selain itu juga sering menjual beberapa produk virtual eksklusif yang memiliki batas waktu dan untuk mendapatkan tersebut biasanya pemain harus bermain game secara intens dan melakukan top-up diamond untuk membeli produk virtual tersebut.

Menurut (Griffths 2015), Alasan mengapa beberapa orang membeli produk-produk virtual karena produk virtual menarik untuk status sosial meskipun tidak memiliki potensi untuk memperkuat karakter dalam permainan. Namun berbeda dengan kenyataan dilapangan dimana membeli produk virtual dalam online games tersebut dapat meningkatkan skill karakter. Ada beberapa produk virtual yang mampu meningkatkan skill saat permainan seperti meningkatkan damage dan mampu mempercepat naiknya level setiap karakter. Alasan unik lainnya dari membeli produk virtual adalah eksklusivitas yaitu membeli barang ekslusif (barang terbatas). Fenomena ini menarik untuk diteliti apa sebenarnya yang mempengaruhi keputusan pembelian produk virtual di dalam online game Mobile Legends. Meskipun begitu, masih banyak ulasan buruk yang diberikan oleh beberapa pemain yang memainkan game Mobile Legends di Google Play Store dan App Store. Keluhan-keluhan seperti sinyal, matching, pembagian tim dan hukuman bagi perilaku pemain satu tim yang AFK (Away From Keyboard) atau istilahnya bagi pemain yang meninggalkan permainan saat permainan sedang berlangsung, dimana hal ini dapat mempengaruhi pemain lainnya. Jika terus dibiarkan maka akan berdampak pada kelangsungan dari game Mobile Legends. Ulasan buruk tersebut dapat 
mempengaruhi para pemain untuk berpindah ke game lain yang sejenis atau tidak karena mereka merasa tidak puas akan game yang dimainkan.

Kepuasan pelanggan merupakan hal yang dapat memengaruhi keputusan pembelian (Ho and $\mathrm{Wu}$ 2012). Semakin puas konsumen maka akan semakin meningkat intensi pembeliannya. Orang-orang yang merasa puas cenderung loyal terhadap game yang dimainkannya. Ketika pemain tersebut loyal, ia cenderung membeli produk virtual yang dijual oleh online game yang dimainkannya. Visual game dan kesenangan bermain juga dapat mendeskripsikan bagaimana pemain online game menilai produk virtual dan dapat memengaruhi mereka untuk membelinya (Park and Lee 2011). Nilai konsumsi juga dapat memengaruhi keputusan pembelian pemain online games untuk membeli produk virtual (Sheth, Newman, and Gross 1991). Cerita didalam game, visual grafik, dan proses pengontrolan karakter berpengaruh besar pada kesenangan bermain, kepuasan pemain juga dapat mempengaruhi keputusan pembelian produk virtual dalam online game (Jiming, Pengtao, and Rao 2008).

Penelitian ini menggunakan teori nilai konsumsi yang dikemukakan oleh (Sheth, Newman, and Gross 1991). Nilai Konsumsi digunakan Untuk mengidentifikasi faktor-faktor yang menentukan keputusan pembelian konsumen pada produk virtual. Teori nilai konsumsi yang digunakan dalam penelitian ini hanya tiga nilai di antara lima nilai tersebut: Nilai Fungsional, Nilai Emosional Dan Nilai Sosial. Nilai fungsional diartikan sebagai nilai dari suatu produk atau jasa yang didapat dan dirasakan berdasarkan fungsi, kegunaan atau sifat fisik produk. Atribut fungsional dan pemikiran rasional mendominasi proses pengambilan keputusan konsumen. Nilai Sosial (Social Values) didefinisikan sebagai Nilai yang dirasakan diperoleh dari interaksi dengan kelompok sosial tertentu. Nilai sosial pada suatu produk atau jasa diperoleh melalui hubungan sosial dengan kelompok etnis sosial ekonomi, demografi, dan budaya. Oleh karena itu, biasanya didorong oleh nilai-nilai sosial untuk menarik konsumsi terhadap produk yang terlihat dan yang terakhir Nilai Emosional (Emotional Values) didefinisikan sebagai nilai utilitas yang dirasakan berasal dari penggunaan suatu produk sehingga menimbulkan perasaan yang kuat akan produk tersebut dan merasa tertarik akan produk tersebut.

Sedangkan untuk 2 nilai lainnya, yaitu nilai epistemik dan nilai kondisional tidak digunakan. Menurut penelitian dari (Park and Lee 2011), nilai kondisional tidak dapat diterapkan pada pembelian produk virtual karena pemain online game dapat melakukannya kapan saja saat mereka inginkan dan pembayarannya juga bisa dilakukan dimana saja dan kapan saja. Sedangkan pada nilai epistemik yang memiliki artian memberikan hal baru bagi konsumen yang berupa pengalaman baru bagi konsumen yang didapat secara langsung contohnya seperti CSR (Corporate Social Responsibility) dan lainnya yang dimana hal itu tidak berlaku pada online game yang memiliki transaksi dan hubungan secara online dengan konsumen. (Ho and Wu 2012) menjelaskan dalam penelitiannya ada 9 faktor yang menentukan keeputusan pembelian produk virtual dalam online game, diantaranya yaitu kompetensi karakter (X1); utilitas harga (X2); kualitas fungsional (X3); kesenangan bermain (X4); estetika (X5); ekspresi citra diri sosial (X6); dukungan hubungan sosial (X7); identifikasi karakter (X8); kepuasan bermain game (X9).

Sebagaimana diuraikan sebelumnya, perkembangan internet menjadi salah satu faktor penting dalam meningkatkan kualitas online game, selain itu juga akan semakin banyak pesaing yang akan menciptakan online game dengan genre yang sejenis sehingga pemain online game memiliki banyak pilihan game yang tersedia di aplikasi Google Play dan App Store. Untuk menjadi yang terdepan, developer harus terus mengembangkan online game mereka agar terus diminati oleh para pemain online game tersebut yang menyebabkan mereka cenderung membeli produk virtual yang dijual oleh online game. Pemain biasanya akan rela menghabiskan banyak uang ketika game yang dimainkan memiliki kualitas yang baik. Penelitian ini dilakukan pada online game Mobile Legends karena memiliki rating yang baik pada aplikasi Google Play dan App Store dan juga Mobile Legends merupakan game yang paling sering diperlombakan pada turnamen baik lokal maupun internasional. Selain itu perlu dilakukankan penelitian terhadap game berjenis MOBA yang dimainkan dalam 
smartphone karena belum adanya penelitian terkait yang meneliti keputusan pembelian produk virtual pada online game berjenis MOBA smartphone.

Tujuan penelitian ini adalah untuk menganalisis (1) faktor-faktor yang menentukan keputusan pembelian produk virtual dan (2) faktor-faktor yang dominan menentukan keputusan pembelian produk virtual dalam online game Mobile Legends. Adapun perbedaan penelitian saat ini dengan penelitian sebelumnya, terletak pada objek, subjek, tempat pengambilan sampel, serta variabel-variabel yang diduga mempengaruhi keputusan pembelian. Objek pada penelitian ini adalah faktor-faktor yang menentukan keputusan pembelian produk virtual Mobile Legends, subjek pada penelitian ini adalah mahasiswa aktif semester 2,4 dan 6 Universitas Pendidikan Ganesha, metode dan tempat pengambilan sampel pada penelitian ini di Universitas Pendidikan Ganesha dan variabel-variabel yang di pilih pada penelitian ini adalah kompetensi karakter, utilitas harga, kualitas fungsional, kesenangan bermain, estetika, ekspresi citra diri sosial, dukungan hubungan sosial, identifikasi karakter dan kepuasan bermain game. Faktor-faktor yang diduga dapat menentukan keputusan pembelian produk virtual dalam Online Games Mobile Legends seperti nampak pada Gambar 1

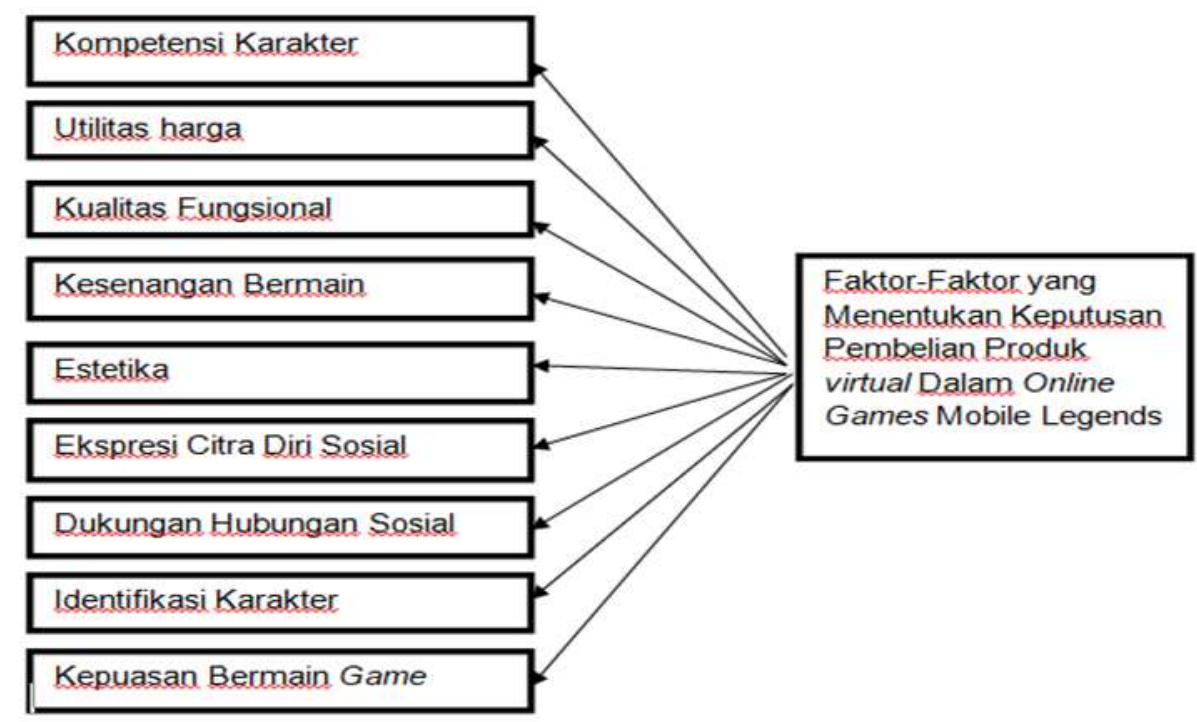

Gambar 1. Kerangka Pemikiran Faktor-Faktor yang Menentukan Keputusan Pembelian Produk Virtual dalam Online Games Mobile Legends.

\section{Metode}

Jenis penelitian ini menggunakan penelitian kuantitatif. Penelitian ini dilakukan untuk mengetahui faktor-faktor apa saja yang mampu menentukan keputusan pembelian konsumen terhadap produk virtual dan untuk mengetahui faktor manakah yang paling dominan menentukan keputusan pembelian konsumen. Faktor yang akan diuji antara lain: kompetensi karakter (X1); utilitas harga (X2); kualitas fungsional (X3); kesenangan bermain (X4); estetika (X5); ekspresi citra diri sosial (X6); dukungan hubungan sosial (X7); identifikasi karakter (X8); dan kepuasan bermain game (X9). Subjek dalam penelitian ini yaitu mahasiswa Universitas Pendidikan Ganesha yang bermain online game Mobile Legends. Sedangkan objek penelitian ini adalah keputusan pembelian. Sampel penelitian ini ditetapkan berdasarkan 5 sampai 10 dikali instrumen yang dibuat (Supranto 2001). Dalam penelitian ini jumlah instrumen adalah 20 , jadi untuk penentuan sampel minimal yaitu $5 \times 20=100$ responden, sedangkan sampel maksimal yaitu $10 \times 20=200$ responden. Sehingga dalam penelitian ini, peneliti menggunakan sampel nimimal yang akan diuji yaitu sebanyak 100 responden. Adapun kriteria responden yaitu: (1) Mahasiswa aktif semester 2,4,6 Universitas Pendidikan Ganesha; (2) Bermain game Mobile Legends lebih dari 1 tahun; (3) Pernah membeli Produk virtual setidaknya lebih dari 2 kali pembelian. 
Teknik pengumpulan data yang digunakan adalah metode penelitian survei dengan menggunakan kuesioner sebagai instrumennya. Metode analisis data yang digunakan adalah analisis faktor. Analisis faktor digunakan untuk mengetahui faktor-faktor yang menentukan keputusan pembelian konsumen. Analisis faktor adalah prosedur yang digunakan untuk mengurangi dan meringkas data tanpa menghilangkan informasi penting dengan beberapa tahapan (Santoso 2004). Tahapan dalam melakukan analisis faktor antara lain: (1) Merumuskan masalah; (2) Membuat matrik korelasi; (3) Menentukan jumlah faktor; (4) Rotasi faktor; (5) Interprestasi faktor; (6) Menentukan ketepatan model.

\section{Hasil dan Pembahasan}

Berdasarkan hasil penelitian yang diperoleh dari 100 responden dengan analisis faktor Kaiser-Meyer-Olkin. Hasil dari pengujian Kaiser-Meyer-Olkin and Barlett of Sphericity Test dapat dilihat pada tabel 1.

Tabel 1 Hasil Pengujian Kaiser-Meyer-Olkin and Bartlett's Test

Kaiser-Meyer-Olkin Measure of Sampling Adequacy. $\quad 0,633$

$\begin{array}{llc} & \text { Approx. Chi-Square } & 235.940 \\ \text { Bartlett's Test of Sphericity } & \text { Df } & 36 \\ & \text { Sig. } & 0,000\end{array}$

Berdasarkan Tabel 1 diperoleh nilai KMO MSA sebesar 0,633, angka tersebut lebih besar dari 0,50 yang artinya jumlah sampel yang digunakan sudah dapat memenuhi syarat. Uji Bartlett's Test dengan Chi-Square sebesar 235.940 dan signifikan pada 0,000, artinya nilai signifikan tersebut kurang dari 0,05 sehingga dapat disimpulkan bahwa uji analisis faktor dapat dilakukan. Tahap selanjutnya adalah menentukan nilai MSA (Measure Of Sampling) yang digunakan untuk dapat mengetahui faktor-faktor yang layak digunakan dalam analisis pemilihan faktor dapat ditentukan dengan anti-image matrix dengan melihat simbol "a" yang memiliki arti untuk MSA (Measure Of Sampling). Faktor-faktor yang layak dalam analisis faktor memiliki nilai diatas 0,50 yang dapat dilihat pada Tabel 2 .

Tabel 2 Hasil Measure of Sampling

\begin{tabular}{ccl}
\hline Variabel & Nilai MSA & \multicolumn{1}{c}{ Keterangan } \\
\hline X1 & 0,795 & Dapat digunakan dalam analisis selanjutnya. \\
X2 & 0,725 & Dapat digunakan dalam analisis selanjutnya. \\
X3 & 0,668 & Dapat digunakan dalam analisis selanjutnya. \\
X4 & 0,800 & Dapat digunakan dalam analisis selanjutnya. \\
X5 & 0,646 & Dapat digunakan dalam analisis selanjutnya. \\
X6 & 0,554 & Dapat digunakan dalam analisis selanjutnya. \\
X7 & 0,537 & Dapat digunakan dalam analisis selanjutnya. \\
X8 & 0,626 & Dapat digunakan dalam analisis selanjutnya. \\
X9 & 0,671 & Dapat digunakan dalam analisis selanjutnya.
\end{tabular}

Berdasarkan Tabel 2 dapat diketahui bahwa dari 9 variabel yang menentukan keputusan pembelian produk virtual dalam online games Mobile Legends dapat digunakan seluruhnya 
karena secara statistik memiliki nilai korelasi MSA diatas 0,50 sehingga dapat digunakan seluruhnya dan dianalisis ke tahap selanjutnya.

Langkah selanjutnya adalah menentukan faktor-faktor tersebut dengan memilih nilai Total Variance Explained untuk menentukan jumlah faktor yang terbentuk, Caranya dengan memilih faktor utama atau komponen dengan parameter akar karakteristik terkecil (total eigenvalue) > 1 yang dapat dilihat pada Tabel 3 .

Tabel 3 Total Variance Explained

\begin{tabular}{ccccccc}
\hline Component & \multicolumn{3}{c}{ Initial Eigenvalues } & \multicolumn{3}{c}{$\begin{array}{c}\text { Extraction Sums of Squared } \\
\text { Loadings }\end{array}$} \\
\cline { 2 - 7 } & Total & $\begin{array}{c}\% \text { of } \\
\text { Variance }\end{array}$ & $\begin{array}{c}\text { Cumulative } \\
\%\end{array}$ & Total & $\begin{array}{c}\% \text { of } \\
\text { Variance }\end{array}$ & $\begin{array}{c}\text { Cumulative } \\
\%\end{array}$ \\
\hline 1 & 2.869 & 31.882 & 31.882 & 2.869 & 31.882 & 31.882 \\
2 & 1.829 & 20.321 & 52.203 & 1.829 & 20.321 & 52.203 \\
3 & 1.039 & 11.540 & 63.743 & 1.039 & 11.540 & 63.743 \\
4 & .955 & 10.615 & 74.359 & & & \\
5 & .706 & 7.849 & 82.208 & & & \\
6 & .494 & 5.486 & 87.693 & & & \\
7 & .471 & 5.231 & 92.924 & & & \\
8 & .376 & 4.182 & 97.106 & & & \\
9 & .260 & 2.894 & 100.000 & & & \\
\hline
\end{tabular}

Berdasarkan Tabel 3 terdapat 3 komponen yang memiliki nilai eigenvalue lebih dari 1, yang diantaranya adalah komponen 1 sebesar 2,869; komponen 2 sebesar 1,829; dan komponen 3 sebesar 1,039. Ketiga komponen memiliki total percentage of variance sebesar $63,743 \%$. Dengan demikian, ketiga komponen tersebut mampu menjelaskan pengaruhnya sebesar $63,743 \%$ terhadap keputusan pembelian produk virtual.

Langkah selanjutnya adalah dengan mengelompokkan faktor menjadi faktor yang baru, sangat penting untuk melakukan rotasi untuk memperjelas faktor yang akan diuji. Jika nilai komponen matrik setiap faktor semakin tinggi, maka semakin kuat hubungannya atau semakin besar pengaruhnya dalam pembentukan faktor keputusan pembelian produk virtual pada Online Games Mobile Legends. Hasil pengujian Rotated Component Matrix tampak pada Tabel 4.

Tabel 4 Rotated Component Matrix

\begin{tabular}{lccc}
\hline & \multicolumn{3}{c}{ Component } \\
\cline { 2 - 4 } & 1 & 2 & 3 \\
\hline Kompetensi karakter & -.027 & .642 & .149 \\
Utilitas Harga & .088 & .700 & .454 \\
Kualitas Fungsional & -.009 & .855 & -.079 \\
Kesenangan Bermain & .147 & .463 & .655 \\
Estetika & .092 & .230 & .732 \\
Ekspresi Citra Diri Sosial & .883 & .028 & .120 \\
Dukungan Hubungan & .713 & .000 & .131 \\
Sosial & .810 & .011 & .026 \\
Identifikasi Karakter & .095 & -.087 & .776 \\
Kepuasan Bermain Game & & & \\
\hline
\end{tabular}


Berdasarkan hasil rotated component matrix, tahap selanjutnya adalah dibuat interpretasi faktor dilakukan dengan pengelompokan faktor-faktor yang menentukan keputusan pembelian produk virtual seperti pada Tabel 5.

Tabel 5. Pengelompokkan Faktor-Faktor yang Menentukan Keputusan Pembelian Produk Virtual dalam Online Games Mobile Legends

\begin{tabular}{|c|c|c|c|c|}
\hline No. & Faktor & $\begin{array}{l}\text { Eigen } \\
\text { value }\end{array}$ & Faktor & $\begin{array}{c}\text { Factor } \\
\text { Loadina }\end{array}$ \\
\hline 1 & Nilai Sosial & 2,869 & $\begin{array}{l}\text { Ekspresi Citra Diri Sosial } \\
\text { Dukungan hubungan sosial } \\
\text { Identifikasi Karakter }\end{array}$ & $\begin{array}{l}0,883 \\
0,713 \\
0,810\end{array}$ \\
\hline 2 & Nilai Fungsional & 1,829 & $\begin{array}{l}\text { Kompetensi karakter } \\
\text { Utilitas harga } \\
\text { Kualitas Fungsional }\end{array}$ & $\begin{array}{l}0,642 \\
0,700 \\
0,855\end{array}$ \\
\hline 3 & Nilai Emosional & 1,039 & $\begin{array}{l}\text { Kesenangan Bermain } \\
\text { Estetika } \\
\text { Kepuasan Bermain Game }\end{array}$ & $\begin{array}{l}0,655 \\
0,732 \\
0,776\end{array}$ \\
\hline
\end{tabular}

Berdasarkan Tabel 5. dapat dijelaskan bahwa faktor-faktor yang menentukan keputusan pembelian produk virtual yang terdiri dari 3 faktor. 3 faktor tersebut terdiri dari nilai sosial, nilai fungsional, dan nilai emosional Komponen 1 dengan nama faktor nilai sosial terdiri dari faktor ekspresi citra diri sosial, dukungan hubungan sosial dan kepuasan bermain game. Faktor nilai sosial dalam teori nilai konsumsi dapat mempengaruhi keputusan pembelian produk virtual di Mobile Legends, dimana nilai sosial dapat membuat seseorang membeli produk karena gaya hidup baru dari kelompok sosial tertentu yang diikutinya, maka dari itu faktor nilai sosial dapat mewakili faktor ekspresi citra diri sosial, dukungan hubungan sosial dan kepuasan bermain game. Komponen 2 dengan nama faktor nilai fungsional terdiri dari faktor kompetensi karakter, utilitas harga dan kualitas fungsional. Faktor nilai fungsional dalam teori nilai konsumsi dapat mempengaruhi keputusan pembelian produk virtual di Mobile Legends, dimana nilai fungsional menjadi alasan utama mengapa orang ingin membeli suatu barang atau jasa karena seseorang mengetahui produk atau jasa yang akan dibeli, maka dari itu faktor nilai fungsional dapat mewakili faktor kompetensi karakter, utilitas harga dan kualitas fungsional. Komponen 3 dengan nama faktor nilai emosional terdiri dari faktor kesenangan bermain, estetika dan kepuasan bermain. Faktor nilai emosional dalam teori nilai konsumsi dapat memengaruhi keputusan pembelian produk virtual di Mobile Legends, dimana nilai emosional didapat karena seseorang menggunakan atau merasakan produk atau jasa yang dibelinya, maka dari itu faktor nilai emosional dapat mewakili faktor kesenangan bermain game, estetika dan kepuasan bermain.

Berdasarkan hasil penelitian yang diperoleh dalam penelitian diatas telah di jabarkan bahwa terdapat 3 faktor baru yang paling dominan dalam menentukan keputusan pembelian produk virtual pada online games Mobile Legends. Adapun faktor tersebut adalah faktor nilai sosial, faktor nilai fungsional dan faktor nilai emosional. Ketiga faktor tersebut memiliki total percentage of variance sebesar $63,743 \%$ yang memiliki arti bahwa faktor tersebut mampu menjelaskan pengaruhnya sebesar $63,743 \%$ dalam keputusan pembelian produk virtual online games Mobile Legends. Sedangkan 36,257\% ditentukan oleh faktor lain. Faktor tersebut dapat dijelaskan sebagai berikut : (1) Faktor 1 (Nilai Sosial) dengan nilai varimax rotation sebesar $31,882 \%$ dengan faktor yang mendominasi yaitu ekspresi citra diri sosial, memiliki loading factor tertinggi sebesar 0,883 sehingga dimensi ekspresi citra diri sosial dominan terhadap keputusan pembelian produk virtual pada online games Mobile Legends.

(2) Faktor 2 (Nilai Fungsional) dengan nilai varimax rotation sebesar 20,321\% dengan faktor yang mendominasi yaitu kualitas fungsional, memiliki loading factor tertinggi sebesar 0,855 
sehingga dimensi kualitas fungsional dominan terhadap keputusan pembelian produk virtual pada online games Mobile Legends. (3) Faktor 3 (Nilai Emosional) dengan nilai varimax rotation sebesar $11,540 \%$ dengan faktor yang mendominasi yaitu kepuasan bermain game, memiliki loading factor tertinggi sebesar 0,776 sehingga dimensi kepuasan bermain game dominan terhadap keputusan pembelian produk virtual pada online games Mobile Legends

Dari ketiga faktor tersebut, dapat dijelaskan bahwa faktor yang paling dominan dalam menentukan keputusan pembelian produk virtual dalam online games Mobile Legends adalah faktor nilai sosial dengan nilai varimax rotation $31,882 \%$.

Hasil penelitian ini menolak teori yang disampaikan oleh (Griffths 2015) dimana produk virtual dapat memiliki potensi memperkuat skill karakter namun mendukung pernyataannya dalam menaikkan status sosial. Selain itu, hasil penelitian ini mendukung teori yang dikemukakan oleh (Jiming, Pengtao, and Rao 2008) dimana kualitas fungsional mempengaruhi keputusan pembelian produk virtual yang diantaranya grafik visual, proses pengontrolan karakter dan latar cerita yang terdapat dalam game. Kualitas fungsional yang baik dan sesuai dengan ekspetasi pemain akan menyebabkan pemain tersebut puas. Pemain online games memiliki beberapa pertimbangan saat akan membeli produk virtual, diantaranya kualitas fungsional, nilai seni dan ekspresi citra diri. Ekpresi citra diri berkaitan dengan nilai sosial yang dapat mendorong pemain untuk membeli produk virtual yang ada pada game (Wijaya and Alamanda 2016). Dengan membeli produk virtual, pemain menganggap dirinya bangga dengan penampilan karakter yang dimainkan dan menaikan status sosialnya merupakan alasan pemain untuk membeli produk virtual. Selain itu, kualitas fungsional juga dapat menjadi pertimbangan lainnya bagi pemain untuk membeli produk virtual. Semakin baik kualitas game semakin puas seorang pemain terhadap game yang dimainkan. Misalnya dengan memperbaiki gameplay dan skill setiap karakter yang dimana hal ini akan memberikan rasa puas ketika game yang dimainkan sesuai dengan apa yang mereka inginkan. Pemain secara tidak langsung dapat mengidentifikasi karakter yang menurut mereka bagus dan dapat mereka mainkan sesuai role mereka. Biasanya pemain mengetahui dari penjelasan yang disampaikan dan cuplikan skill dari setiap karakter. Developer dapat melakukan updating pada setiap karakter dengan menunjukkan skill dengan bahasa yang lebih mudah, sehingga pemain langsung memahami setiap karakter dan membelinya sesuai kebutuhan mereka.

Pengaruh promosi yang dilakukan oleh pihak developer juga dapat mempengaruhi emosional dari pemain untuk membeli produk virtual. Pihak developer bisa menggunakan cara seperti memperbanyak event-event agar pemain semakin antusias untuk membeli produk virtual. Contohnya seperti, memberikan gratis diamond setelah melalukan top-up diamond dengan syarat tertentu atau perbanyak skin hero sesuai bulan atau hari-hari nasional juga dapat menjadi pilihan bagi developer untuk menarik pemain agar dapat membeli produk virtual.

\section{Simpulan dan Saran}

Berdasarkan dari hasil penelitian yang diperoleh, dapat ditarik kesimpulan yaitu faktor yang menentukan keputusan pembelian produk virtual pada online games Mobile Legends adalah Faktor 1 dengan nama faktor nilai sosial yang terdiri dari ekspresi citra diri sosial, dukungan hubungan sosial, dan identifikasi karakter. Faktor 2 dengan nama faktor nilai fungsional yang terdiri dari kompetensi karakter, utilitas harga dan kualitas fungsional. Faktor 3 dengan nama faktor nilai emosional yang terdiri dari kesenangan bermain, estetika dan kepuasan bermain game. Faktor yang paling dominan dalam menentukan keputusan pembelian produk virtual dalam online games Mobile Legends adalah faktor nilai sosial dengan nilai varimax rotation $31,882 \%$.

Saran yang dapat diberikan untuk penelitian berikutnya adalah peneliti dapat menggunakan faktor-faktor lainnya untuk menguji keputusan pembelian produk virtual. Selain itu peneliti juga dapat menambah populasi penelitian dengan menggunakan online games dengan jenis yang berbeda dari penelitian ini dan menggunakan teknik analisis yang berbeda. Dari pengembangan yang dilakukan tersebut, tentunya semakin banyak penelitian mengenai keputusan pembelian produk virtual. Selain itu hasil penelitian ini juga dapat dijadikan bahan 
pertimbangan untuk pihak developer Mobile Legends ataupun developer game sejenis secara umum.

\section{Daftar Pustaka}

Asosiasi Penyelenggara Jasa Internet Indonesia. 2018. Penetrasi Dan Profil Pengguna Internet.

Dongseong, Choi, and Kim Jinwoo. 2004. "Why People Continue to Play Online Games: In Search of Critical Design Factors to Increase Customer Loyalty to Online Contents." CyberPsychology and Behavior.

Griffths, Mark. 2015. "Money for Nothing (and Your Clicks for Free?): Why Do Gamers Buy 'Virtual Assets'?" Drmarkgriffiths.

Ho, Cheng-Hsun, and Ting-Yun Wu. 2012. "Factors Affecting Intent To Purchase Virtual Goods in Online Games." International Journal of Electronic Business Management 10(3): 20412.

Jiming, Wu, Li Pengtao, and Shashank Rao. 2008. "Why They Enjoy Virtual Game Worlds? An Empirical Investigation." Journal of Electronic Commerce Research.

Kaburuan, Emil R., Chien Hsu Chen, and Tay Sheng Jeng. 2009. “Identifying Users' Behavior Purchasing Virtual Items." Proceedings of the International Conference on Electronic Business (ICEB) 2: 250-56.

Kevino, Satya. 2018. "Apa Itu MOBA?” https://esportsnesia.com/.

Newzoo. 2019. NewZoo Global Game Market Report.

Park, Bong Won, and Kun Chang Lee. 2011. "Exploring the Value of Purchasing Online Game Items." Computers in Human Behavior 27(6): 2178-85.

Santoso, Singgih. 2004. Mengatasi Berbagai Masalah Statistik Dengan SPSS Versi 11,5. 5th ed. Jakarta: PT. Elex Media Komputido.

Sari, Winda. 2018. "Kepuasan Dengan Permainan, Identifikasi Karakter Dan Nilai Konsumsi Terhadap Niat Beli Produk Virtual." Jurnal Ekonomi dan Manajemen 19(2).

Sheth, Jagdish N., Bruce I. Newman, and Barbara L. Gross. 1991. "Why We Buy What We Buy: A Theory of Consumption Values." Journal of Business Research 22(2): 159-70.

Supranto, J. 2001. Statistika Teori Dan Aplikasi, Cetakan Kedua. Jakarta: Penerbit Erlangga.

Suryono, Ryan Randy, and Apol Pribadi Subriadi. 2016. "Perilaku Pemain Game Online Terhadap Pembelian Virtual Item." Sisfo 05(05): 578-84.

Wijaya, Akbar Nugroho, and Dini Turipanam Alamanda. 2016. "Kajian Teori Nilai Konsumsi Terhadap Pembelian Barang Virtual Pada Game Online Moba." e-Proceeding of Management 3(1): 165-75.

Yulius, Rina. 2017. "Analisis Perilaku Pengguna Dalam Pembelian Item Virtual Pada Game Online." Journal of Animation and Games Studies 3(1). 